Article

\title{
Transcriptome Analysis of Paraburkholderia phymatum under Nitrogen Starvation and during Symbiosis with Phaseolus Vulgaris
}

\author{
Martina Lardi, Yilei Liu, Gabriela Purtschert, Samanta Bolzan de Campos (iD and \\ Gabriella Pessi * \\ Department of Plant and Microbial Biology, University of Zurich, $\mathrm{CH}-8057$ Zurich, Switzerland; \\ martina.lardi@uzh.ch (M.L.); yilei.liu@botinst.uzh.ch (Y.L.); gabriela.p@access.uzh.ch (G.Pu.); \\ samanta.bolzandecampos@botinst.uzh.ch (S.B.d.C.) \\ * Correspondence: gabriella.pessi@botinst.uzh.ch; Tel.: +41-44-6352904
}

Received: 31 October 2017; Accepted: 4 December 2017; Published: 15 December 2017

\begin{abstract}
Paraburkholderia phymatum belongs to the $\beta$-subclass of proteobacteria. It has recently been shown to be able to nodulate and fix nitrogen in symbiosis with several mimosoid and papilionoid legumes. In contrast to the symbiosis of legumes with $\alpha$-proteobacteria, very little is known about the molecular determinants underlying the successful establishment of this mutualistic relationship with $\beta$-proteobacteria. In this study, we performed an RNA-sequencing (RNA-seq) analysis of free-living P. phymatum growing under nitrogen-replete and -limited conditions, the latter partially mimicking the situation in nitrogen-deprived soils. Among the genes upregulated under nitrogen limitation, we found genes involved in exopolysaccharides production and in motility, two traits relevant for plant root infection. Next, RNA-seq data of P. phymatum grown under free-living conditions and from symbiotic root nodules of Phaseolus vulgaris (common bean) were generated and compared. Among the genes highly upregulated during symbiosis, we identified-besides the nif gene cluster-an operon encoding a potential cytochrome o ubiquinol oxidase (Bphy_3646-49). Bean root nodules induced by a $c y o B$ mutant strain showed reduced nitrogenase and nitrogen fixation abilities, suggesting an important role of the cytochrome for respiration inside the nodule. The analysis of mutant strains for the RNA polymerase transcription factor RpoN $\left(\sigma^{54}\right)$ and its activator NifA indicated that-similar to the situation in $\alpha$-rhizobia-P. phymatum RpoN and NifA are key regulators during symbiosis with $P$. vulgaris.
\end{abstract}

Keywords: differential gene expression; rhizobia; infection; nitrogen fixation; nodulation; NifA; cytochrome; sigma factor; exopolysaccharides; motility

\section{Introduction}

Symbiotic nitrogen fixation (SNF) by rhizobia in root nodules of several legumes accounts for a fourth of the $\mathrm{N}_{2}$ fixed annually on Earth [1]. Legume-nodulating rhizobia are polyphyletic and include hundreds of species from 14 genera of two bacterial classes: $\alpha$-proteobacteria $(\alpha$-rhizobia) and $\beta$-proteobacteria ( $\beta$-rhizobia). The fact that legumes could be nodulated also by $\beta$-rhizobia was discovered with the isolation of two Burkholderia strains (Burkholderia tuberum STM678 ${ }^{\mathrm{T}}$ and Burkholderia phymatum $\mathrm{STM} 815^{\mathrm{T}}$ ) from the root nodules of the South African legumes Aspalathus carnosa and Cyclopia spp. [2,3] as well as from Mimosa spp. [4,5], and with the isolation of Cupriavidus taiwanensis from the nodules of invasive Mimosa species in Taiwan [6]. Phylogenetic analyses based on symbiotic genes, such as the nitrogen fixation (nif) and nodulation (nod) genes, suggested that 
$\beta$-rhizobia have existed as legume symbionts for approximately 50 million years, and that they have evolved separately from $\alpha$-rhizobia [7-9]. Although the South American and Asian $\beta$-rhizobia are associated with Mimosa, an increasing number of South African $\beta$-rhizobia that are associated with diverse papilionoid legumes have been described [3,10-16]. In addition, naturally occurring symbioses between the papilionoid legumes from the genera Rhynchosia, Dipogon and Burkholderia strains harboring South African-type nod genes have been reported $[12,17,18]$. Phylogenomics approaches led to the proposal to reclassify nodulating and nitrogen-fixing Burkholderia species into the new genus Paraburkholderia $[19,20]$. So far, 17 nodulating Paraburkholderia species have been described: P. tuberum, P. phymatum [21], P. mimosarum [22], P. nodosa [23], P. sabiae [24], P. caribensis [25], P. diazotrophica [26], P. caballeronis [27], P. phenoliruptrix [25], P. sprentiae [28], P. rhynchosiae [29], P. dilworthii [30], P. aspalathi [31], P. kirstenboschensis [32], P. dipogonis [33], P. piptadeniae, and $P$. ribeironis [34]. Currently, only one nodulating and nitrogen-fixing Burkholderia strain, B. symbiotica, is not a member of the Paraburkholderia genus, but instead belongs to the so called "P. rhizoxinica group" [35].

Nitrogen is the most often limiting nutrient for crop production worldwide, and the Rhizobium-legume symbiosis plays a significant role in improving the fertility and productivity of low-N soils. In unfertilized soils, free-living rhizobia developed mechanisms to facilitate $\mathrm{N}_{2}$ scavenging from alternative nitrogen sources [36]. The nitrogen regulatory (Ntr) response plays a key role and involves the action of signal transduction PII proteins and of the two-component regulatory system NtrBC [36]. The transcriptional regulator NtrC, together with the alternative ofactor $\sigma^{54}$ (or RpoN), activates the transcription of genes involved in nitrogen assimilation, such as the glutamine synthetase $(g \ln A)$ and the ammonium transporter $(a m t B)$. Certain bacteria, such as Azotobacter, Klebsiella, and P. phymatum have been shown to be able to convert atmospheric nitrogen $\left(\mathrm{N}_{2}\right)$ into ammonia in free-living conditions [4,37]. Inside legumes root nodules, rhizobia activate $\mathrm{N}_{2}$ fixation and generate ammonia to meet the large needs of the plant. In $\alpha$-rhizobia, the expression of the symbiotic nitrogen fixation genes (nif, coding for the nitrogenase polypeptides, and fix, encoding nitrogenase cofactors) is activated by a cascade of signals, which involves low oxygen-sensing regulators such as NifA [38] and FixLJ [39].

For the well-known $\alpha$-rhizobial symbioses, the different steps leading to a functional root nodule have been characterized in detail [36,40], while for $\beta$-rhizobia, very little is known about the molecular mechanisms required to establish and support a symbiosis with their respective host plants. Previous comparative genomics analyses [41-43] indicated that, apart from the nod-nif symbiotic modules, very few genes were specifically shared by the phyletic distinct $\alpha$ - and $\beta$-rhizobia, suggesting mechanistic differences between $\alpha$-and $\beta$-rhizobial symbioses. As an example, the $c b b_{3}$-type cytochrome oxidase present in all $\alpha$-rhizobia was not detected in any of the Paraburkholderia genomes [44]. Our model system consists of P. phymatum STM815 ${ }^{\mathrm{T}}$ as the rhizobial partner and the agriculturally important legume Phaseolus vulgaris (common bean) as the host legume. P. phymatum STM $815^{\mathrm{T}}$ was first shown to enter symbiosis with Mimosa spp. by Elliott and co-workers [4], and many strains have been subsequently isolated from M. pudica in both its native and invasive range [4,45,46], strongly suggesting that the original host of $\mathrm{STM} 815^{\mathrm{T}}$ was a Mimosa species native to South America [5]. P. phymatum STM $815^{\mathrm{T}}$ has since been shown to be highly promiscuous, capable of effectively nodulating several Mimosa spp. and many other related mimosoid genera [47,48], as well as some legumes in the papilionoid tribe Phaseoleae that are normally nodulated by South African Paraburkholderia $[15,17]$.

The goal of this study was to gain a better understanding about the genetic basis underlying a $\beta$-rhizobial, nitrogen-fixing symbiosis. More specifically, we investigated P. phymatum gene expression profile (i) in cells underlying nitrogen starvation, a condition that partially resembles the one that free-living rhizobia encounter in nitrogen-deprived soils before infecting the roots, and (ii) during symbiosis with $P$. vulgaris.

RNA-sequencing (RNA-seq) experiments showed that P. phymatum responded to nitrogen limitation by activating genes involved in the assimilation of nitrogen sources, as well as genes 
involved in exopolysaccharides (EPS) biosynthesis and motility. These two characteristics were shown in $\alpha$-rhizobia to be important for the root infection process. The transcriptome of $P$. phymatum inside bean root nodules revealed that-apart from genes involved in nitrogen fixation-other genes potentially important for a symbiotic lifestyle were significantly upregulated in nodules. Mutant strain analyses in planta suggested that a cytochrome o ubiquinol oxidase gene cluster (Bphy_3646-49) is important for symbiosis with P. vulgaris. Moreover, we show here that two key regulators of nitrogenase expression in $\alpha$-rhizobia [38], the alternative $\sigma$ factor RpoN (or $\sigma^{54}$ ) and its activator NifA, are equally important for $\beta$-rhizobial symbiosis. Additionally, RpoN controls the utilization of nitrate and urea as nitrogen sources, as well as EPS formation.

Finally, this study describes the characterization of three genes important for P. phymatum $P$. vulgaris symbiosis and provides a rich source of information for the discovery of new functions potentially important for the establishment of the symbiotic interaction between $\beta$-rhizobia and papilionoid legumes.

\section{Materials and Methods}

\subsection{Bacterial Strains, Media, and Cultivation}

The bacterial strains, plasmids, and primers employed in this work are listed in Table S1. Escherichia coli was grown in Luria-Bertani medium (LB [49]; $10 \mathrm{~g}$ of tryptone, $5 \mathrm{~g}$ of yeast extract and $4 \mathrm{~g} \mathrm{NaCl}$ per liter), whereas $P$. phymatum cells were cultivated under aerobic conditions in the modified LB medium without salt. The following antibiotic concentrations were used: chloramphenicol $(20 \mu \mathrm{g} / \mathrm{mL}$ for E. coli and $80 \mu \mathrm{g} / \mathrm{mL}$ for P. phymatum), kanamycin $(25 \mu \mathrm{g} / \mathrm{mL}$ for E. coli and $50 \mu \mathrm{g} / \mathrm{mL}$ for P. phymatum), and nalidixic acid $50 \mu \mathrm{g} / \mathrm{mL}$ for P. phymatum. The bacterial cultures for the transcriptomic studies were grown in defined buffered $\mathrm{AB}$ minimal medium [50] with $10 \mathrm{mM}$ sodium citrate as the carbon source, supplemented with trace elements [51]. Nitrogen-replete conditions $(\mathrm{N})$ were achieved with $30 \mathrm{mM}$ ammonium chloride $\left(\mathrm{NH}_{4} \mathrm{Cl}\right)$, whereas $0.5 \mathrm{mM} \mathrm{NH}_{4} \mathrm{Cl}$ was used to obtain nitrogen-limited (S) conditions. The cultures of P. phymatum were grown in $250 \mathrm{~mL}$ Erlenmeyer flasks containing $100 \mathrm{~mL}$ of medium that were incubated at $30^{\circ} \mathrm{C}$ with shaking at $180 \mathrm{rpm}$ for approximately $24 \mathrm{~h}$. The microoxic cultures in $\mathrm{AB}$ minimal medium were prepared and grown as previously described [52] in $50 \mathrm{~mL}$ of medium in $500 \mathrm{~mL}$ rubber-stoppered serum bottles containing $0.5 \%$ oxygen (PanGas, Zurich, Switzerland) and 99.5\% nitrogen (PanGas, Zurich, Switzerland). The bottles were shaken at $80 \mathrm{rpm}$; every $9-15 \mathrm{~h}$, the gas phase was exchanged.

The growth of all P. phymatum strains (wild type (wt), rpoN mutant, and rpoN complemented) was tested with three different nitrogen substrates: ammonium $(30 \mathrm{mM})$, nitrate $(30 \mathrm{mM})$, and urea $(15 \mathrm{mM})$. For each tested strain, the growth of at least two independent cultures was measured.

\subsection{Plant Growth Conditions and Inoculation}

Common bean seedlings (Phaseolus vulgaris, cv. Negro jamapa, kindly provided by Professor Eulogio Bedmar, Granada, Spain) were surface-sterilized as previously described [53]. The seeds were deposited on $0.8 \%$ agar plates and incubated in the dark at $30^{\circ} \mathrm{C}$. After two days, the germinated seedlings were planted into autoclaved yoghurt jars containing vermiculite (VTT-Group, Muttenz, Switzerland) and $170 \mathrm{~mL}$ diluted Jensen medium [54]. The cells were washed twice in AB minimal medium without nitrogen, and $1 \mathrm{~mL}$ of the desired bacterial strains $\left(10^{5}\right.$ bacterial cells) was directly inoculated on the germinated seedling. The plants were grown in the following conditions: the temperature was kept at $22{ }^{\circ} \mathrm{C}$ at night and $25{ }^{\circ} \mathrm{C}$ during the day; light was supplied for approximately $16 \mathrm{~h}$; humidity was $60 \%$. The root nodules were harvested 21 days post infection (dpi) for analysis. 


\subsection{Determination of Symbiotic Properties}

Several symbiotic properties (nodule number, nodule dry weight, nitrogenase activity, and $\mathrm{N}$ content) were determined as described previously [55-57]. Bean plants inoculated with P. phymatum were harvested 21 days post infection (dpi), and the number of nodules on each root was counted. The nodules were dried at $65^{\circ} \mathrm{C}$ overnight. The nitrogenase activity was determined by an acetylene reduction assay (ARA). In detail, $1 \mathrm{~mL}$ of acetylene (PanGas, Zurich, Switzerland) was injected in a $50 \mathrm{~mL}$ tube (Infochroma AG, Zug, Switzerland) containing the root of interest. After co-incubation with the root, $25 \mu \mathrm{L}$ of the gas from the tube was injected into a gas chromatograph (Agilent, Santa Clara, CA, USA) to analyze the nitrogenase activity, which is represented by the percentage of the ethylene over the acetylene peak [56]. The results were normalized by the dry weight of all the nodules on the plants and the incubation time. At least two independent experiments with five plants per strain were performed. The $\mathrm{N}$ content of the shoot was calculated as described before, using the Dumas method (combustion) [57]. Approximately $600 \mu \mathrm{L}$ of flash-frozen nodules (corresponding roughly to 40 nodules) infected by $P$. phymatum wild type were used for a transcriptome experiment.

\subsection{RNA-Sequencing and Data Processing}

Total RNA from P. phymatum cells grown under free-living nitrogen-replete, nitrogen-limited, or microoxic conditions (see Section 2.1) to the end of the exponential growth phase (optical density at $600 \mathrm{~nm}$ of $0.7,0.4$, or 0.5 , respectively), and from $600 \mu \mathrm{L}$ of flash-frozen root nodules was extracted using a modified hot acid phenol protocol [58]. The nodule samples were subjected to an additional acid phenol treatment. Three independent biological replicates were performed per sample. The verification of the complete removal of genomic DNA and a quality check of the RNA were performed as previously described [59]. After DNase treatment, the nodule sample was processed with the Ribo-zero ${ }^{\mathrm{TM}}$ Plant-Seed/Root kit (Epicentre, Madison, WI, USA) to remove plant ribosomal RNA (rRNA). After RNA quantification, 100-350 ng were used for cDNA synthesis. Library preparations and purifications were performed using the Encore Complete Prokaryotic RNA-Seq DR Muliplex System (NuGEN, San Carlos, CA, USA), which uses a novel Insert-Dependent Adaptor Cleavage (InDAC) technology for the removal of bacterial rRNA transcripts. Before sequencing, the cDNA libraries were quantified by capillary electrophoresis using the Agilent D1000 Screen Tape System (Agilent, Santa Clara, CA, USA). Illumina single-end sequencing was performed using the HiSeq2500 instrument. Sequence reads were processed and mapped to the P. phymatum STM $815^{\mathrm{T}}$ genome [48] using CLC Genomics Workbench v7.0 (QIAGEN CLC bio, Aarhus, Denmark), allowing up to two mismatches per read. The unique mapped reads were statistically analyzed for differential expression using the DESeq R-package v1.26 [60]. For DESeq analysis, the top 200 and 500 significantly regulated genes (ranked by ascending $p$-value) were taken into account for nitrogen-limited versus nitrogen-replete (a small regulon was expected), and for symbiotic versus free-living conditions (substantial changes in the expression were expected), respectively. The functional classification of the differentially expressed genes was performed using eggNOG v3.0 [61]. The RNA-seq raw data files are accessible through the GEO Series accession number GSE107381.

\subsection{Quantitative Reverse Transcription PCR ( $q R T-P C R)$ Analysis}

The differential expression of P. phymatum genes, namely, Bphy_0257 (amtB), Bphy_0326 ( rpoN), Bphy_1479 (ntrC), Bphy_1481 (glnA), Bphy_3648 (cyoB), Bphy_7728 (nifA), and Bphy_7753 (nifH) was assessed as previously described [59] by quantitative reverse transcription-PCR (qRT-PCR) using the Brilliant III Ultra-Fast SYBR green QPCR master mix (Agilent, Santa Clara, CA, USA) and a Mx3000P instrument (Agilent). Samples of cDNAs were produced as previously described [52]. Three different dilutions (15, 7.5 and $3.75 \mathrm{ng}$ ) of each cDNA were used as qRT-PCR templates, and each reaction was done in triplicates. The $\triangle \triangle C T$ method was used to calculate the fold changes in expression [62] using 
the sigma factor rpoD (Bphy_3690) as a housekeeping gene for normalization. For all the primers pairs, an annealing temperature between $55-58{ }^{\circ} \mathrm{C}$ was used.

\subsection{Construction of Paraburkholderia phymatum STM815T Mutant Strains}

The genomic DNA (gDNA) of P. phymatum was isolated using the DNeasy Blood \& Tissue kit (Qiagen, Hilden, Germany), whereas the plasmid DNA from E. coli strains was extracted with the QIAprep Spin Miniprep kit (Qiagen). To generate mutant strains, a 300-500 bp-long internal fragment of the genes of interest (nifA, $c y o B$ and $r p o N$ ) was amplified with Phusion High-Fidelity DNA polymerase (ThermoFischer, Waltham, MA, USA), using the primers listed in Table S1 (Bphy_x_IM_F and $\mathrm{R}$, where " $\mathrm{x}$ " is the gene name). The PCR products of nifA and rpoN were cloned into pGEM-T Easy (Promega, Madison, WI, USA) and then subcloned into pSHAFT2 as EcoRI or NotI fragments for nifA and rpoN. For $c y o B$, the PCR product was digested and directly cloned into the digested pSHAFT2 as EcoRI fragment. The resulting plasmids pSHAFT-nifA, pSHAFT-cyoB, and pSHAFT-rpoN were then mobilized into wild-type P. phymatum by triparental mating using E. coli pRK2013 as a helper strain, generating P. phymatum nifA mutant (nifA mt, STM815-nif $\left.\mathrm{A}_{\mathrm{Pp}}\right), c y o B$ mutant (cyoB mt, STM815-cyoB $\left.B_{\mathrm{Pp}}\right)$, and $r p o N$ mutant $\left(r p o N \mathrm{mt}\right.$, STM815-rpoN $\mathrm{Pp}_{\mathrm{Pp}}$ ). The correct genomic integration was verified by PCR using the external oligonucleotides Bphy_nifA_check_F, Bphy_cyoB_check_R, or Bphy_rpoN_check_R in combination with pSHAFTseqFor (Table S1). To construct a cyoAB deletional mutant strain, one $452 \mathrm{bp}$-long fragment (fragment 1), flanking upstream of the gene $c y o A$ (Bphy_3649), and one 448 bp-long fragment (fragment 2), flanking downstream of cyoB (Bphy_3648), were chosen as recombination sites for deletion mutation. Fragment 1 was amplified with the primers Bphy3649up_XhoI and Bphy3649up_XbaI and fragment 2 was amplified with the primers Bphy3648down_XbaI and Bphy3648down_NotI, using the gDNA of P. phymatum as a template. Both fragments were digested with $\mathrm{XbaI}$ and ligated together. The ligated DNA was amplified by PCR using Bphy3649up_XhoI and Bphy3648down_NotI, then digested by XhoI and NotI, and subcloned into pSHAFT2. A kanamycin cassette was cut out from pKD4 plasmid using XbaI and inserted between the two fragments in PSHAFT2 vector. The resulting plasmid was mobilized into a P. phymatum strain, spontaneously resistant to nalidixic acid (NAL, STM815 ${ }_{\mathrm{Nal}}$ ), that we generated through spontaneous mutation. In details, $10^{8} \mathrm{P}$. phymatum wild-type cells were plated onto a Tryptone Yeast (TY) agar plate [63] containing nalidixic acid $100 \mu \mathrm{g} / \mathrm{mL}$, and the survived clones were subsequently purified onto a TY plate containing nalidixic acid $50 \mu \mathrm{g} / \mathrm{mL}$. The $c y o A B$ deletion mutant $\left(\triangle c y o A B\right.$, STM $\left.815_{\mathrm{Nal}} \triangle c y o A B\right)$ was confirmed by PCR using the primers KM_F (annealing to the kanamycin resistance cassette) and Bphy3648_out (annealing to the neighboring gene Bphy_3647).

To complement the rpoN mutant strain, the complete Bphy_0326 open reading frame (ORF) was amplified using the Phusion High-Fidelity DNA polymerase (ThermoFischer), by using the oligonucleotides Bphy_rpoN_c_F/R. The PCR product was digested with BamHI and XbaI and cloned into the corresponding sites of pBBR1MSC-2. The complementing plasmid was mobilized into the corresponding P. phymatum mutant strain by triparental mating, resulting in the P. phymatum rpoN complemented strain (rpoN comp). For all the primers pairs, an annealing temperature between $55-58{ }^{\circ} \mathrm{C}$ was employed.

\subsection{Exopolysaccharides Production}

Exopolysaccharides production was tested on modified YEM medium plates (1\% mannitol, $0.06 \%$ yeast extract) as previously described $[57,64]$. The plates were incubated for 4 days at $30^{\circ} \mathrm{C}$.

\subsection{Statistical Analysis}

The symbiotic properties (nodule number per plant, dry weight per nodule, relative nitrogenase activity, and $\mathrm{N}$ content) were analyzed statistically with ANOVA and Tukey's tests, using the Prism 7 software (version 7.0; La Jolla, CA, USA). For categories distribution, the percentages of upregulated or downregulated genes in each category were calculated by dividing 
the number of up- and downregulated genes in each category by the total number of genes grouped in the corresponding category. Fischer tests were carried out (online calculator of GraphPad) to assess a possible over- or under-representation of the functional eggNOG categories.

\section{Results}

\subsection{Transcript Profiling of P. phymatum STM815 ${ }^{T}$ in Response to Nitrogen Limitation}

RNA-seq was employed to first investigate the molecular mechanisms underlying the response to nitrogen limitation in P. phymatum, a condition which partially mimics the situation that rhizobia encounter in nitrogen-starved soils. For this, wild-type cells were grown in minimal medium supplemented with ammonium (among the best nitrogen sources used by P. phymatum in a Biolog PM3 plate [65]) under nitrogen-replete $\left(\mathrm{N}, 30 \mathrm{mM} \mathrm{NH} \mathrm{Nl}_{4} \mathrm{Cl}\right.$ ) and nitrogen-starved $\left(\mathrm{S}, 0.5 \mathrm{mM} \mathrm{NH}_{4} \mathrm{Cl}\right)$ conditions. From both conditions, three independent biological replicates were processed and sequenced. Reads uniquely mapping to the genome were subjected to a statistical and comparative analysis using DESeq [60]. A graphical visualization of the read intensity (mean of the normalized reads) versus the logarithm (base 2) of the fold change (FC; nitrogen-limited versus nitrogen-replete conditions) are illustrated in Figure 1A. The top 200 differentially expressed genes under nitrogen-limited and -replete conditions are listed in Table S2 ( $p$-value $\leq 0.02$ and absolute $\log _{2}$ (fold change) $\geq 0.87$ ). Out of these, 79 genes showed increased expression when the cells were grown under nitrogen-limiting conditions.

To explore the functional relevance of the differentially expressed genes, the top 200 nitrogen-regulated genes were assigned to functional categories according to the eggNOG classification system [61]. Certain categories were found to be significantly over-represented: category E (amino acid transport and metabolism), category P (inorganic ion transport and metabolism), and category $\mathrm{T}$ (signal transduction mechanisms) (Figure 1B). Among the top differentially expressed genes, several belonged to category $\mathrm{E}$ including genes involved in urea transport (Bphy_2251 to Bphy_2254) and ureA (Bphy_2258), coding for a urease. Some other genes known to be relevant for nitrogen control in several other bacteria $[66,67]$ were found in category $\mathrm{P}$, such as amtB (ammonium transporter, Bphy_0257) and an assimilatory nitrate reductase gene (Bphy_5659-60) with its transporter gene (Bphy_3974-78, excluding Bphy_3975). Finally, a substantial number of transcriptional regulators were classified in category $\mathrm{T}$. These included the nitrogen metabolism transcriptional regulatory gene $n \operatorname{trC}$ (Bphy_1479) and the gene coding for a methyl-accepting chemotaxis sensory transducer (Bphy_ 2338), which was the most significantly upregulated gene in nitrogen starvation (Table S2). The gene belonging to a potential EPS cluster (Bphy_1071, the BCAM1005 orthologue in B. cenocepacia J2315), as well as the genes coding for a polyhydroxybutyrate (PHB)-associated protein (phasin, Bphy_1467) and for three depolymerases potentially involved in polyhydroxyalkanoates (PHA) and PHB biosynthesis (Bphy_4313, Bphy_4407, and Bphy_5512) also showed significantly enhanced expression under nitrogen-starving conditions. To validate the expression changes observed in the RNA-seq data, several regulated genes important for nitrogen utilization $(a m t B, n t r C, r p o N$, and $g \ln A$ ) were subjected to quantitative reverse transcription PCR (Table 1). 
(A)

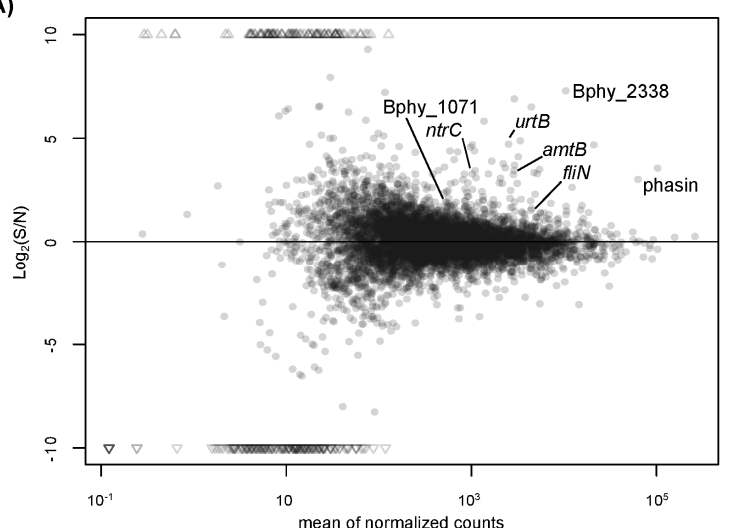

(B)

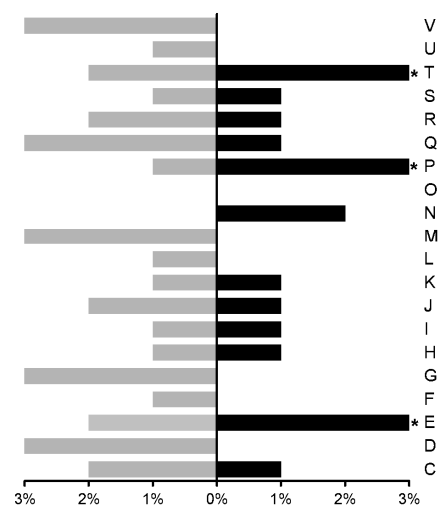

Figure 1. Analysis of the Paraburkholderia phymatum transcriptome in response to nitrogen limitation. The MA plot (M log ratios; A averages of normalized counts) displays the logarithm (base 2) of the fold changes in transcripts expression of cells grown under nitrogen-limited (S) versus nitrogen-replete (N) conditions, and the mean of the normalized reads (A). Functional categories of the top 200 differentially expressed genes (genes induced in nitrogen starvation are in black, those repressed in grey) according to the eggNOG annotation (B). The asterisks $\left({ }^{*}\right)$ indicate statistical significance for over-represented genes in a particular category ( $p$-value $<0.01)$. C, energy production and conversion; $\mathrm{E}$, amino acid transport and metabolism; F, nucleotide transport and metabolism; G, carbohydrate transport and metabolism; H, coenzyme transport and metabolism; I, lipid transport and metabolism; J, translation, ribosomal structure, and biogenesis; $\mathrm{K}$, transcription; $\mathrm{L}$, replication, recombination, and repair; $\mathrm{M}$, cell wall, membrane, and envelope biogenesis; $\mathrm{N}$, cell motility; $\mathrm{O}$, post-translational modification, protein turnover, and chaperon; $\mathrm{P}$, inorganic ion transport and metabolism; $\mathrm{Q}$, secondary metabolites biosynthesis, transport, and catabolism; R, general function prediction only; S, function unknown; $\mathrm{T}$, signal transduction mechanisms; $\mathrm{U}$, intracellular trafficking, secretion, and vesicular transport; $\mathrm{V}$, defense mechanisms.

Table 1. Quantitative reverse transcription PCR (qRT-PCR) and RNA-sequencing (RNA-seq) analysis of genes with induced expression under nitrogen-starved conditions.

\begin{tabular}{|c|c|c|c|c|}
\hline Locus ID $^{1}$ & Description $^{1}$ & Gene Name & FC $(\mathrm{S} \text { vs. } \mathrm{N})^{2}$ & FC $(\mathrm{S} \text { vs. N})^{3}$ \\
\hline Bphy_0257 & Ammonium transporter & $a m t B$ & $19.7 \pm 4.6$ & 10.9 \\
\hline Bphy_0326 & RNA polymerase factor $\sigma^{54}$ & rpoN & $1.4 \pm 0.1$ & 0.7 \\
\hline Bphy_1479 & $\begin{array}{l}\text { Nitrogen metabolism } \\
\text { transcriptional regulator }\end{array}$ & $n t r C$ & $8.8 \pm 1.2$ & 9.7 \\
\hline Bphy_1481 & Glutamine synthetase, type I & $g \ln A$ & $4.0 \pm 0.8$ & 1.9 \\
\hline
\end{tabular}

${ }^{1}$ Locus identifier and description is given according to the GenBank files (NC_010622.1, NC_010623.1, NC_010625.1, NC_010627.1); ${ }^{2}$ fold change (FC) in qRT-PCR expression by comparing the wild-type strain grown under nitrogen-limited (S) and nitrogen-replete conditions (N); ${ }^{3}$ fold change (FC) determined by DESeq analysis comparing the transcriptome profile of cells grown under nitrogen-limited (S) and nitrogen-replete conditions (N). 


\subsection{Transcript Profiling of P. phymatum STM815 ${ }^{T}$ during Symbiosis with P. vulgaris}

Next, we investigated the whole transcript profile of P. phymatum during symbiosis. For this, bean root nodules induced by $P$. phymatum wild-type were processed 21 days after infection for a RNA-seq analysis. The RNA from $P$. phymatum cells grown in minimal medium under aerobic conditions was used to provide a gene expression baseline for comparison. Among three independent biological replicates per condition, we obtained-per nodule sample-between 4.2 and 5.3 million reads uniquely mapping to the P. phymatum genome. The transcript profiles of P. phymatum grown under symbiotic and free-living conditions were compared by DESeq analysis. Among the top 500 differentially expressed genes (DESeq analysis $p$-value $\leq 0.01$ and absolute $\log _{2}$ (Fold change) $\geq 1.6$ ) (Table S3), 322 were significantly upregulated. Out of these $322,32 \%$ are located on the symbiotic plasmid $(0.59 \mathrm{Mb}), 28 \%$ on chromosome $1(3.48 \mathrm{Mb}), 22 \%$ on chromosome $2(2.7 \mathrm{Mb})$, and $18 \%$ on plasmid $1(1.9 \mathrm{Mb})$ (Figure $2 \mathrm{~B})$. This indicated a strong enrichment of regulated genes on the symbiotic plasmid that otherwise harbors only $6 \%$ of the genes of the whole genome (Figure 2A). Furthermore, the top 500 differentially regulated genes were assigned to functional categories (Figure 2C). Among these, 178 showed significant decreased expression in nodules. As displayed in Figure 2C, the eggNOG category N (cell motility) comprised $21 \%$ of the genes downregulated inside the nodule. A couple of them were involved in flagellar biosynthesis (Bphy_2940-41, fliOP; Bphy_2962, flgF). In addition, category U (intracellular trafficking, secretion, and vesicular transport), which contains a partial cluster for a type IV secretion system (Bphy_7525 to Bphy_7536), was significantly over-represented among the genes with reduced expression inside the nodule. Analysis of the 322 genes significantly upregulated in nodules, indicated that category $\mathrm{C}$ (energy production and conversion) was over-represented, among which were the genes known to be important for symbiotic functions such as nitrogen fixation (nif cluster) and hydrogenase (Figure 3A,B). We also found a gene coding for an isocitrate lyase (Bphy_1368) and a potential cytochrome o ubiquinol oxidase cluster (Bphy_3646-49), which may play a role for respiration inside the nodule (Figure $3 C$ ). In the over-represented functional category P (inorganic ion transport and metabolism) we identified several ATP-binding cassette (ABC)-transporters for sulfate (Bphy_1627 and Bphy_1629), nitrate/sulphonate/bicarbonate (Bphy_3603), phosphate (Bphy_3120 and Bphy_4622), aliphatic sulphonate (Bphy_5226), taurine (Bphy_6080), and urea (Bphy_2251-52). In addition, two interesting genes displayed increased expression in nodules: Bphy_1467, coding for a phasin-like protein potentially involved in PHB stability, and a PHB depolymerase (Bphy_4407). In order to mimic the transition towards conditions of extremely low oxygen inside the nodules, we additionally grew P. phymatum under microoxic conditions (supplemented with $0.5 \%$ oxygen) and performed a transcriptome analysis [68]. As expected, under microoxic conditions the genes coding for the nitrogenase were highly expressed and upregulated (Table 2). The cytochrome o ubiquinol oxidase cluster (Bphy_3646-49) that was upregulated in symbiosis also showed increased expression under reduced oxygen availability (Table 2). The upregulated genes belonging to several of the over-represented categories discussed above are listed in Table 3. 


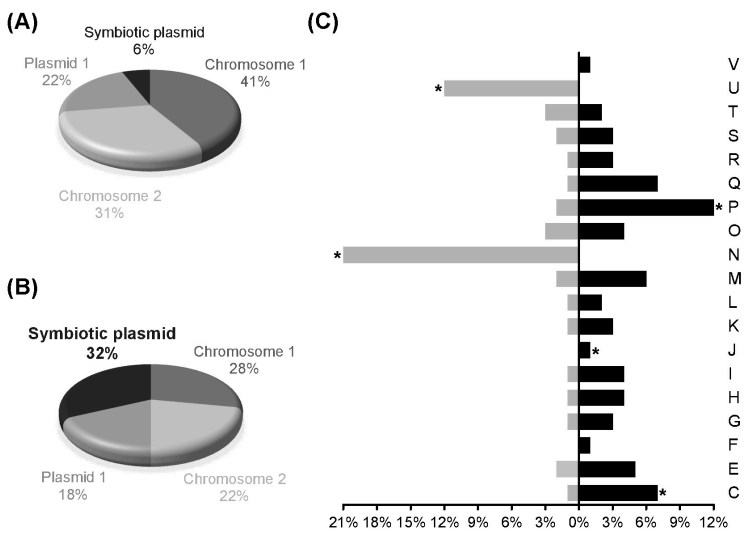

Figure 2. Analysis of the transcripts differentially expressed during symbiosis of P. phymatum with P. vulgaris. Percentages of the gene distribution among the two chromosomes and two plasmids of the P. phymatum genome (A), and percentages of the 322 genes significantly induced during symbiosis with respect to their encoding chromosomes or plasmids (B). Functional categories of the 500 differentially expressed genes (genes induced in bacteroids shown in black, genes repressed shown in grey) according to the eggNOG annotation (C). The 322 genes used for the calculation of the percentages distribution in (B) were obtained from the analysis performed with the $\mathrm{R}$ package DESeq $\left(p\right.$-value $\left.\leq 0.01, \log _{2}(\mathrm{FC}) \geq 1.6\right)$. Asterisks $\left(^{*}\right)$ indicate statistical significance for over-represented genes in a particular category $(p$-value $<0.01)$.

Table 2. qRT-PCR and RNA-seq analysis of genes with induced expression during symbiosis and microoxic conditions.

\begin{tabular}{|c|c|c|c|c|}
\hline Locus ID ${ }^{1}$ & Description $^{1}$ & Gene Name & $\begin{array}{l}\text { FC (Bacteroids vs. } \\
\text { Free-Living) }^{2}\end{array}$ & FC (MO vs. O $)^{3}$ \\
\hline Bphy_0326 & RNA polymerase factor $\sigma^{54}$ & $r p o N$ & $2.1 \pm 0.5$ & 1.6 \\
\hline Bphy_1479 & Nitrogen metabolism transcriptional regulator & $n t r C$ & $6.6 \pm 1.6$ & 0.9 \\
\hline Bphy_3648 & Cytochrome o ubiquinol oxidase, subunit I & cyoB & $201.8 \pm 44.0$ & 68.3 \\
\hline Bphy_7728 & Transcriptional regulator & nifA & $19.1 \pm 2.4$ & 4.2 \\
\hline Bphy_7753 & Nitrogenase reductase & nifH & $898.4 \pm 174.2$ & 567.0 \\
\hline
\end{tabular}

${ }^{1}$ Locus identifier and description is given according to the GenBank files (NC_010622.1, NC_010623.1, NC_010625.1, NC_010627.1); ${ }^{2}$ fold change (FC) in qRT-PCR expression for the wild-type strain grown in symbiotic conditions (bacteroids) compared to free-living conditions; ${ }^{3}$ fold change (FC) determined by DESeq analysis comparing the transcriptome profile of cells grown in microoxic conditions $(\mathrm{MO})$ with that of cells grown under oxic conditions $(\mathrm{O})$.

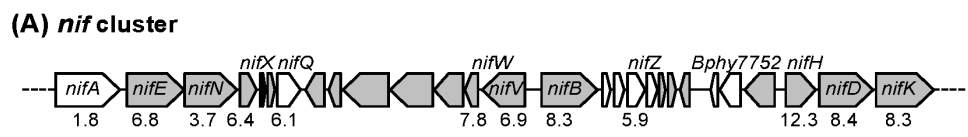

(B) Hydrogenase cluster

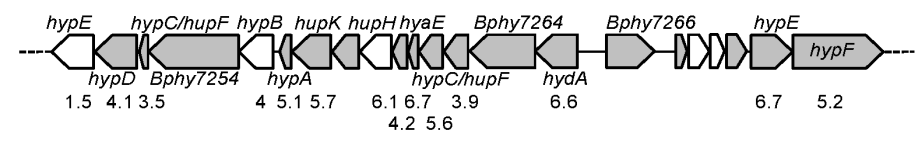

(C) Potential oxidase cluster

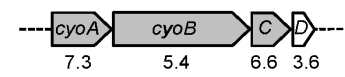

Figure 3. Selected P. phymatum gene clusters showing statistically significant upregulation under symbiotic compared to free-living conditions. The following gene clusters are represented: nitrogen fixation (nif) (A), hydrogenase (B), and a potential cytochrome o ubiquinol oxidase cluster (C). Gene names are indicated in italic, and the logarithm (base 2) of the fold changes is shown underneath. Genes listed within the top 500 regulated genes (Table S3) are colored in grey. 
Table 3. List of 68 genes showing increased expression in bacteroids compared to free-living conditions and belonging to an over-represented eggNOG category (Fischer test $p$-value $<0.01$ ).

\begin{tabular}{|c|c|c|c|}
\hline Locus ID $^{1}$ & Description $^{1}$ & $\begin{array}{l}\text { Gene } \\
\text { Name }\end{array}$ & $\begin{array}{c}\log _{2} \mathrm{FC} \text { (Bacteroids vs. } \\
\text { Free-Living) }{ }^{2}\end{array}$ \\
\hline \multicolumn{4}{|c|}{ Energy production and conversion } \\
\hline Bphy_1649 & alkanesulfonate monooxygenase & & 6.0 \\
\hline Bphy_1848 & 2-oxoacid dehydrogenase subunit E1 & & 2.9 \\
\hline Bphy_2272 & FAD linked oxidase domain-containing protein & & 2.9 \\
\hline Bphy_3649 & ubiquinol oxidase, subunit II & cyoA & 7.3 \\
\hline Bphy_3685 & phosphate acetyltransferase & & 2.0 \\
\hline Bphy_4116 & rubrerythrin & & 1.9 \\
\hline Bphy_4949 & aldehyde dehydrogenase & & 2.6 \\
\hline Bphy_5235 & alkanesulfonate monooxygenase & & 6.2 \\
\hline Bphy_5817 & putative flavodoxin & & 3.6 \\
\hline Bphy_6055 & hypothetical protein & & INF \\
\hline Bphy_6673 & aldehyde oxidase and xanthine dehydrogenase molybdopterin binding & & 4.5 \\
\hline Bphy_7231 & cytochrome ce class I & & 2.8 \\
\hline Bphy_7232 & xenobiotic (desulfurization)monooxygenase subunit A & & 5.3 \\
\hline Bphy_7262 & hydrogenase expression/formation protein & & 5.6 \\
\hline Bphy_7263 & $\mathrm{Ni} / \mathrm{Fe}$-hydrogenase, b-type cytochrome subunit & & 3.9 \\
\hline Bphy_7264 & nickel-dependent hydrogenase large subunit & & 6.4 \\
\hline Bphy_7265 & hydrogenase $(\mathrm{NiFe})$ small subunit & hydA & 6.6 \\
\hline Bphy_7406 & aldehyde dehydrogenase & & 7.3 \\
\hline Bphy_7729 & nitrogenase MoFe cofactor biosynthesis protein & nifE & 6.8 \\
\hline Bphy_7730 & nitrogenase molybdenum-cofactor biosynthesis protein & $\operatorname{nifN}$ & 3.7 \\
\hline Bphy_7733 & ferredoxin III, nif-specific & & 6.3 \\
\hline Bphy_7737 & electron-transferring-flavoprotein dehydrogenase & fixC & 6.8 \\
\hline Bphy_0883 & phosphate transporter permease subunit & pstC & 2.5 \\
\hline Bphy_0885 & phosphate transporter ATP-binding protein & & 2.6 \\
\hline Bphy_1627 & sulfate $\mathrm{ABC}$ transporter inner membrane subunit & cysW & 2.2 \\
\hline Bphy_1629 & sulfate $\mathrm{ABC}$ transporter, periplasmic protein & & 5.2 \\
\hline Bphy_1647 & $\mathrm{ABC}$ transporter-like protein & & 5.9 \\
\hline Bphy_1648 & binding-protein-dependent transport systems & & 3.3 \\
\hline Bphy_2231 & sulfate adenylyltransferase large subunit & & 2.3 \\
\hline Bphy_2521 & catalase & & 4.9 \\
\hline Bphy_3120 & phosphate $\mathrm{ABC}$ transporter, periplasmic protein & & 4.2 \\
\hline Bphy_3602 & $\mathrm{ABC}$ transporter related & & 4.0 \\
\hline Bphy_3603 & nitrate/sulfonate/bicarbonate $\mathrm{ABC}$ transporter, periplasmic protein & & 2.6 \\
\hline Bphy_3854 & phosphate transporter & & 2.7 \\
\hline Bphy_4233 & Rieske (2Fe-2S) domain-containing protein & & 2.9 \\
\hline Bphy_4622 & phosphonate $\mathrm{ABC}$ transporter binding protein & & 6.7 \\
\hline Bphy_5040 & lipoprotein & & 7.8 \\
\hline Bphy_5065 & 2-aminoethylphosphonate $\mathrm{ABC}$ transporter, 2-aminoethylphosphonate binding protein & & 2.0 \\
\hline Bphy_5226 & aliphatic sulfonate $\mathrm{ABC}$ transporter, periplasmic protein & & 4.0 \\
\hline Bphy_5227 & substrate-binding region of ABC-type glycine betaine transport system & & 9.0 \\
\hline Bphy_5229 & aliphatic sulfonate $\mathrm{ABC}$ transporter, periplasmic protein & & 5.8 \\
\hline Bphy_5232 & rhodanese domain-containing protein & & 5.6 \\
\hline Bphy_6080 & taurine $\mathrm{ABC}$ transporter, periplasmic binding protein & & 7.5 \\
\hline Bphy_6081 & $\mathrm{ABC}$ transporter related & & 4.2 \\
\hline Bphy_6550 & metallophosphoesterase & & 3.5 \\
\hline Bphy_7233 & $\mathrm{ABC}$ transporter related & & 3.7 \\
\hline Bphy_7234 & binding-protein-dependent transport systems & & 4.6 \\
\hline
\end{tabular}


Table 3. Cont.

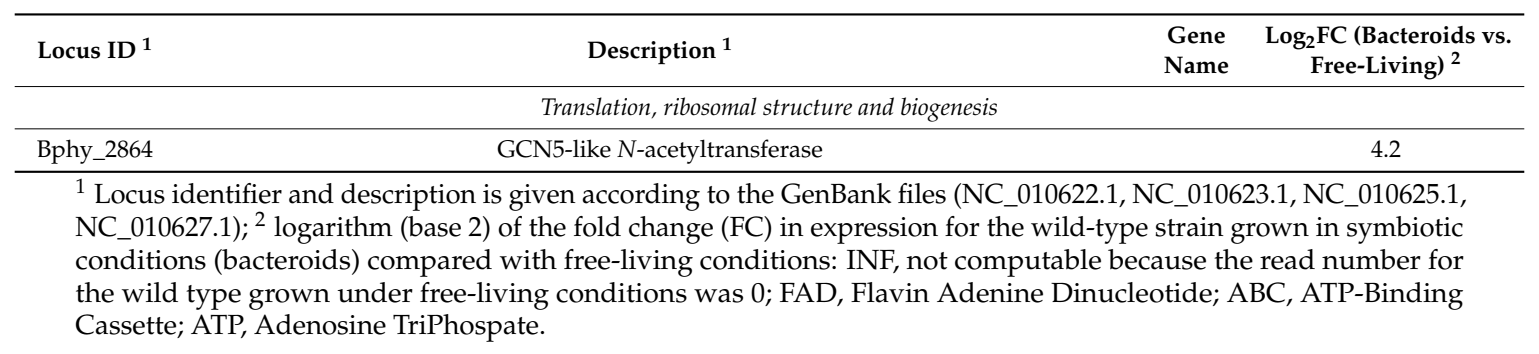

We observed an overlap of 38 genes with increased expression in both nitrogen-limited growth conditions (Table S2) and during symbiosis with bean (Table S3). Among those, we found two genes involved in PHB production: phaP (Bphy_1467), encoding a phasin regulating PHB stability by binding to PHB-granula [69], and a PHB depolymerase (Bphy_4407). The regulatory gene $n t r C$, which is part of the two-component regulatory system (2CRS) NtrB/NtrC, known to be important for nitrogen control in other organisms [64], also showed significantly higher expression under nitrogen-limited conditions and during symbiosis.

A complete list with all P. phymatum genes and logarithm (base 2) of the fold changes in expression in nitrogen-starved versus -replete conditions, as well as during symbiosis is shown in Table S4.

\subsection{Role of nifA, rpoN, and cyoB Genes during Symbiosis}

The transcription of the nif genes in $\alpha$-rhizobia is regulated by the key regulator NifA $[38,70]$, which works together with the $\sigma$ factor RpoN $\left(\sigma^{54}\right)$. Remarkably, P. phymatum lacks the typical high-oxygen-affinity $c b b_{3}$-type cytochrome oxidase present in $\alpha$-rhizobia [44], but a potential cytochrome o ubiquinol oxidase cluster (Bphy_3646-49) was found among the significantly and highly upregulated genes inside the nodule (Table 3). To investigate the role of the nifA, rpoN, and $c y o B$ genes during symbiosis in our $\beta$-rhizobial model system, P. phymatum nifA (Bphy_7728), rpoN (Bphy_0326), and cyoB (Bphy_3648) mutant strains were constructed, as well as a $\triangle c y o A B$ deletion mutant. The deletion mutant was generated using a strain resistant to nalidixic acid (NAL) as a baseline (see Section 2.6).

First, the growth of the four mutant strains (nifA, $r p o N, c y o B$, and $\triangle c y o A B$ ), as well as of the wild type $(\mathrm{wt})$ and of the nalidixic acid-resistant wild-type (NAL) was monitored in microaerobic conditions $\left(0.5 \% \mathrm{O}_{2}\right)$, i.e., in conditions that mimic those inside the nodules. In general, a slight growth delay of the mutant strains (nifA, $c y o B$, and $\triangle c y o A B$ ) compared to the wild-type was observed. On the contrary, the rpoN mutant strain displayed faster growth in the exponential phase, but finally reached a similar final optical density at $\lambda=600 \mathrm{~nm}\left(\mathrm{OD}_{600}\right)$ (Figure 4).

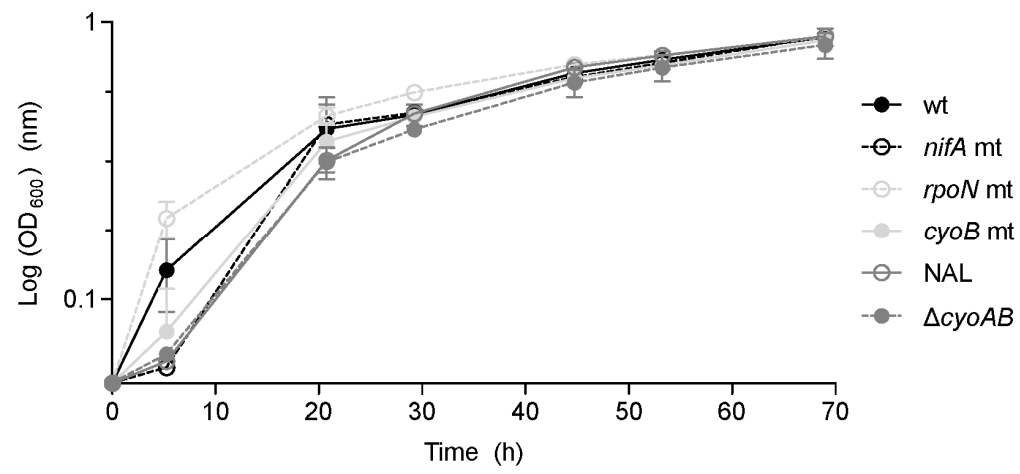

Figure 4. Growth of $P$. phymatum wild-type (wt), nalidixic acid-resistant wild-type (NAL), and mutant (mt) strains (nifA, rpoN, cyoB, and $\triangle c y o A B$ ) under microoxic conditions (see Section 2.1). Whiskers indicate standard deviation (SD), $n \geq 2$. OD 600 , Optical density at $\lambda=600 \mathrm{~nm}$. 
The relevance of these genes during symbiotic life was then tested using our host legume P. vulgaris (bean). The same amount of colony forming units $\left(\mathrm{CFU} ; 10^{5}\right)$ of wild-type and mutant strain cells was inoculated on bean seedlings. After 3 weeks of growth in the green house, several key symbiotic parameters of the nodules, such as their number, the dry weight, their relative nitrogenase activity, as well as their $\mathrm{N}$ content were determined. At 21 days post infection (dpi), the roots inoculated with the nifA mutant strain had significantly more nodules compared to bean plants inoculated with the other strains (Figure 5A). No significant difference in the overall nodule number was observed for the other mutant strains compared to their respective wild type. However, the dry weight per nodule of plants infected by the nifA mutant strain was comparable to that of plants inoculated with either the wild type or the rpoN mutant strains (Figure 5B). In contrast to the nodules induced by the wild-type strain, those induced by the nif $A$ and $r p o N$ mutant strains showed no nitrogenase activity (Figure 5C). The nodules induced by the $c y o B$ and the $\triangle c y o A B$ mutants showed a $65 \%$ and $75 \%$ reduction in the relative nitrogenase activity compared to their wild-type strain, respectively. In line with the results for the nitrogenase activity, plants infected with a nifA or an rpoN mutant had an $\mathrm{N}$-content comparable with that of uninfected bean plants. This was significantly lower than the $\mathrm{N}$-content measured in plants containing P. phymatum wild type (Figure 5D). Plants infected by the $c y o B$ mutant and the $\triangle c y o A B$ strains displayed an $\mathrm{N}$-content that was similar to the one of uninoculated plants. Together, these results suggest that, besides nif $A$ and $r p o N$, also $c y o B$ plays an important role for an efficient establishment of a symbiosis with bean.

(A)

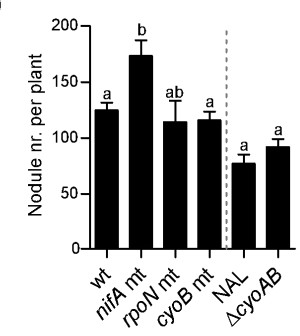

(C)

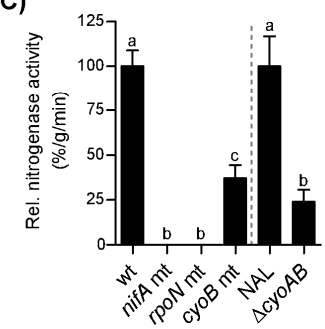

(B)

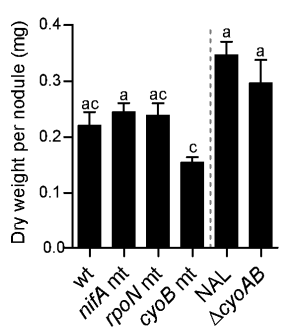

(D)

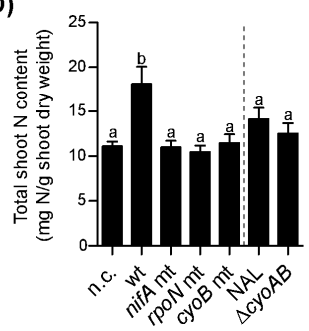

Figure 5. Comparison of the symbiotic properties of $P$. vulgaris (bean) plants inoculated with different P. phymatum wild-type and mutant strains: wild-type (wt) and the respective nifA, $r p o N, c y o B$ mutants, as well as a nalidixic acid-resistant wild-type strain (NAL) and the respective $\triangle c y o A B$ mutant. Number of nodules per plant (A), dry weight per nodule (B), relative nitrogenase activity (C), and nitrogen content (D) were quantified $21 \mathrm{dpi}$. Here, the combined results of at least two independent experiments are shown. Error bars indicate the standard error of the mean (SEM). For each histogram, values with the same letter are not significantly different (as assessed with ANOVA, Tukey's test with $p$-value $\leq 0.05)$. Histograms after the grey dashed line were analyzed by an unpaired student $t$-test ( $p$-value $\leq 0.05)$; the values with the same letter are not statistically significant.

\subsection{Role of RpoN in Free-Living Conditions}

It is known from several bacteria that $\mathrm{RpoN}\left(\sigma^{54}\right)$ is involved in the assimilation of nitrogen sources [59,71,72]. To investigate if $\sigma^{54}$ has a similar role in P. phymatum, we examined the ability of the wild-type, the rpoN mutant, and the complemented rpoN strains to grow in minimal medium in the presence of different nitrogen sources. We found that the rpoN mutant strain was unable to utilize 
nitrate $\left(\mathrm{NO}_{3}{ }^{-}\right)$and urea $\left(\mathrm{CH}_{4} \mathrm{~N}_{2} \mathrm{O}\right)$ as sole nitrogen sources, and that this defect could be restored in the rpoN complemented strain (Table 4). As expected, the nifA mutant strain was not impaired in the utilization of the tested nitrogen sources. Taken together, these results suggested that RpoN is involved in the regulation of nitrite and urea assimilation in P. phymatum.

Table 4. Utilization of various nitrogen sources by P. phymatum wild type, nifA, rpoN mutant, and rpoN complemented strains ${ }^{1}$.

\begin{tabular}{ccccc}
\hline \multirow{2}{*}{ Nitrogen Source (s) } & \multicolumn{4}{c}{ Utilization of Nitrogen } \\
\cline { 2 - 5 } & wt & nifA mt & rpoN mt & rpoN complemented \\
\hline $30 \mathrm{mM} \mathrm{NH}_{4} \mathrm{Cl}$ & + & + & + & + \\
$0.5 \mathrm{mM} \mathrm{NH}_{4} \mathrm{Cl}$ & + & + & + & \pm \\
$30 \mathrm{mM} \mathrm{NO}_{3}-$ & + & + & - & + \\
$15 \mathrm{mM} \mathrm{CH}_{4} \mathrm{~N}_{2} \mathrm{O}$ & + & + & - & + \\
\hline
\end{tabular}

${ }^{1}$ Growth was assessed with at least two independent replicates by measuring the optical density at $600 \mathrm{~nm}$ after incubation in $\mathrm{ABC}$ minimal medium supplemented with several nitrogen sources for $30 \mathrm{~h}$ at $30^{\circ} \mathrm{C}$ and $220 \mathrm{rpm}$. The " + " sign corresponds to $\mathrm{OD}_{600} \geq 0.6$ for ammonium, $\geq 0.3$ for nitrate, and $\geq 0.6$ for urea; the " \pm " sign corresponds to $\mathrm{OD}_{600} \geq 0.4$ for ammonium.

Since EPS production has been shown to be dependent on the availability of nitrogen sources and on the presence of RpoN [59,73], EPS production by the wild-type, the rpoN mutant, and the complemented strains, as well as by the nifA strain (as control), was examined on Yeast Extract Mannitol medium (YEM) plates containing $1 \%$ mannitol and $0.06 \%$ yeast extract. While the $r p o N$ mutant strain (Figure 6) displayed a reduced amount of EPS compared to the wild type, the nifA mutant and the rpoN complemented strain produced wild-type levels of EPS. Interestingly, when YEM medium was supplemented with $0.6 \%$ of yeast extract, there was nearly no visible difference between the rpoN mutant strain and the wild-type strain in EPS production (data not shown), suggesting that rpoN controls EPS production under nitrogen starvation.

wt

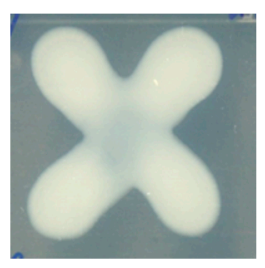

nifA mt

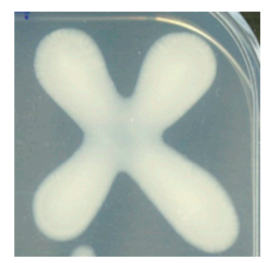

rpoN mt

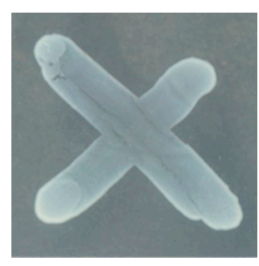

rpoN comp

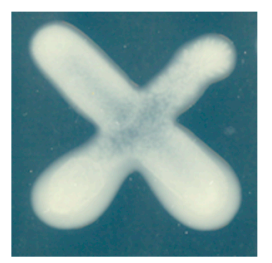

Figure 6. Exopolysaccharide (EPS) production of the nif $A$ mutant, the rpoN mutant, and the complemented strains tested on plates supplemented with $0.06 \%$ of yeast extract. Plates were incubated for four days. At least three independent replicates were performed per strain.

\section{Discussion}

Members of the $\beta$-proteobacterial have been discovered in 2001 to be able to enter a nitrogen-fixing symbiosis with legumes [4]. In contrast to the $\alpha$-rhizobial symbiosis with host legumes, where the different steps leading to the establishment of a successful symbiosis are well studied, very little is known about the molecular mechanisms that are relevant for these steps in $\beta$-rhizobial symbioses. Here, we used an RNA-sequencing approach to provide a comprehensive view on the gene expression profile of P. phymatum grown in either normal or nitrogen-limited free-living conditions, and as bacteroids in symbiosis with $P$. vulgaris. To the best of our knowledge, this is the first transcriptome study from root nodules formed by a $\beta$-rhizobial strain. By testing the gene expression profile in nitrogen-limited conditions, we aimed to partially mimic the conditions that rhizobia encounter in soils lacking nitrogen and in our laboratory settings before colonizing the roots of legumes. 
Apart from genes involved in nitrogen metabolism, a gene cluster potentially involved in EPS biosynthesis (Bhy_1056-Bphy_1077) showed increased expression when nitrogen became limited. Exopolysaccharides were shown in several rhizobia to be required for root hairs attachment [74] and infection [75], the first two steps of the cascade. The gene that showed the most significant and the second highest upregulation during nitrogen starvation encodes for a potential methyl-accepting chemotaxis sensory transducer (Bphy_2338). The presence of another gene involved in motility among the top regulated genes (the flagellar gene fliL) suggests that the cells react to a nitrogen-limited environment by changing their movement behavior, which is a crucial trait for the successful colonization and infection of host legume roots [76]. The future construction and characterization of mutant strains will shed light on the importance of EPS and flagella in a nitrogen-starved environment. The expression of nod genes, encoding the P. phymatum Nod factor required for the recognition of the symbiotic partner, changed only slightly in response to nitrogen starvation (Figure S1). The expression of genes in the nif cluster did not significantly change when the cells were grown under nitrogen limitation, suggesting that-similar to the situation in $\alpha$-rhizobia-the presence of a reduced amount of nitrogen is not sufficient to activate the expression of the nif cluster. In contrast, a low-oxygen environment highly induced the expression of the genes coding for the nitrogenase (Table 2). Among the 38 genes commonly upregulated, we found $n \operatorname{tr} C$, which codes for a transcriptional regulators known to be important for nitrogen control (Ntr) in other organisms [64]. While the Ntr system is usually switched off during nitrogen fixation in symbiotic $\alpha$-rhizobia [36], in free-living diazotrophs such as Azospirillum brasilense the two-component regulatory system NtrB/NtrC has been shown to be involved in the regulation of nitrogenase activity [77]. Two genes coding for a urea $A B C$ transporter (Bphy_2251-52) were also among the genes commonly induced under nitrogen-starving and symbiotic conditions. This may suggest that this organic compound serves an important role in free-living and symbiotic metabolism.

As expected, the expression of the nif gene cluster (including genes from Bphy_7728 to Bphy_7755, Figure 3A), was found significantly upregulated inside nodules induced by P. phymatum. Unlike most $\alpha$-rhizobia [78], P. phymatum contains a nifV homolog in the genome (upstream of nifB), which is also highly induced during symbiosis. This gene encodes a homocitrate synthase that synthesizes homocitrate- - component of the Fe-Mo cofactor of the nitrogenase-which has been shown to be important in diazotrophs to reduce $\mathrm{N}_{2}$ in free-living conditions [79-81]. The presence of nif $V$ in P. phymatum may explain the ability of this bacterium to fix nitrogen in free-living conditions [4]. Among the upregulated genes in symbiosis, we found a potential four-component oxidase cluster also annotated as a cytochrome o ubiquinol oxidase complex. This cluster (Bphy_3646-49, cyoABCD) was also significantly upregulated in a preliminary transcriptome analysis performed on free-living cells grown in microaerobic conditions compared to cells growing aerobically, suggesting that this heme-copper respiratory oxidase could be used by P. phymatum to respire inside root nodules. Indeed, the classical $\mathrm{Cbb}_{3}$-oxidase crucial for symbiosis in $\alpha$-rhizobia was detected neither in the P. phymatum genome nor in other symbiotic Paraburkholderia species [44]. The construction of a $c y o B$ insertion mutant and a $c y o A B$ deletion mutant provided proof that this cluster is indeed important for an efficient symbiotic interaction. Bean plants inoculated with these mutants showed a significantly reduced nitrogenase activity and a lower $\mathrm{N}$ content compared to plants infected with the wild type. In previous studies [82,83], three genes were shown to be important during symbiosis with $M$. pudica: Bphy_0456, involved in the biosynthesis of branched-chain amino acids, Bphy_0685, coding for a fructose 1,6-bisphosphatase, and Bphy_0266 (gpmA), coding for a phosphoglycerate mutase. The expression of these three genes was not regulated in bean root nodules compared to free-living conditions, suggesting that $P$. phymatum may upregulate a different set of genes in its natural host plant Mimosa. Interestingly, and in contrast to the situation in $\alpha$-rhizobia [84,85], a gene coding for an isocitrate lyase (Bphy_1368) was found inside the top 500 regulated genes in P. phymatum bacteroids, suggesting that the glyoxylate shunt pathway is active during $\beta$-rhizobial symbiosis. In previous studies on Bradyrhizobium sp. ORS278, the 
$c c b L 1$ gene, which codes for a ribulose 1,5 bis-phosphate carboxylase oxygenase (RuBisCO) needed for carbon fixation, was proven to have a critical role in symbiotic nitrogen fixation [86]. We noticed here that the P. phymatum gene coding for ribulose-1,5-bisphosphate carboxylase/oxygenase (RuBisCO; Bphy_6497, 77\% amino acid identity to $c c b L 1$ or BRADO1659 of Bradyrhizobium sp. ORS278) was also upregulated inside root nodules, suggesting a possible role of this enzyme also in $\beta$-rhizobial symbiosis. The mutation of two P. phymatum regulatory genes known to play a key role for $\alpha$-rhizobial symbiosis [38] — the alternative sigma factor RpoN and its activator NifA—showed that both regulators are also important for the regulation of nitrogenase activity (Figure 5C). Nodules infected by a nifA mutant strain were impaired in nitrogen fixation, even 28 dpi [87]. An increased number of nodules in grape-like structures were produced in plants infected with the P. phymatum nifA mutant strain. A similar phenotype was observed in the nodules of another legume, soybean, that were induced by a Bradyrhizobium diazoefficiens nifA mutant [88]. Using a metabolomics approach on Bradyrhizobium diazoefficiens nodules, we previously speculated that such a phenotype could be due to a defense reaction of the legume evoked by the nifA mutant, involving an increased production of phytoalexins [89]. Since NifA is an activator protein of the alternative sigma factor $\sigma^{54}$ (RpoN), we constructed an rpoN mutant, which indeed did not show any nitrogenase activity. In addition, the rpoN gene was found highly expressed in all conditions tested, i.e., nitrogen-replete and -limited conditions and during symbiosis, suggesting that RpoN may play an important role not only in symbiosis but also in free-living conditions. In fact, the utilization of nitrogen sources as well as the EPS production were affected in this strain. In a closely related Burkholderia strain belonging to the pathogenic clade, RpoN was shown to play a role in free-living conditions and also in vivo, where a mutant showed reduced virulence in the Caenorhabditis elegans infection model [59].

In summary, this first analysis of bacterial gene expression in symbiotic bean root nodules induced by a $\beta$-rhizobial strain revealed new insights into this recently discovered symbiosis. It provides a rich basis for a further dissection of the molecular mechanisms underlying this symbiotic association and for the elucidation of the mechanistic differences between $\beta$-rhizobial and the much better characterized $\alpha$-rhizobial symbioses.

Supplementary Materials: The following are available online at www.mdpi.com/2073-4425/8/12/389/s1. Figure S1: P. phymatum nodulation (nod) gene cluster. Gene names are indicated in italic, whereas the logarithm (base 2) of the fold changes in transcript expression of the genes under nitrogen-limiting conditions are shown underneath. The upregulated genes $\left(\log _{2} \mathrm{FC} \geq 0.5\right)$ are colored in grey, Table S1: bacterial strains, plasmids, and oligonucleotides used in this study; Table S2: list of the top 200 differentially regulated genes in nitrogen-starved (S) versus nitrogen-repleted $(\mathrm{N})$ conditions (DESeq analysis; $p$-value $\leq 0.02$, absolute $\log _{2}[\mathrm{FC}] \geq 0.87$ ); Table S3: list of the top 500 differentially regulated genes in bacteroids compared to free-living conditions (DESeq analysis; $p$-value $\leq 0.01$ and absolute $\log _{2}$ (Fold change) $\geq 1.6$ ); Table S4: list of all P. phymatum genes with the logarithm (base 2) of the fold changes in expression, and the $p$-values in nitrogen-starved (S) versus -replete (N) conditions, as well as during symbiosis versus free-living conditions, as calculated by DESeq analysis.

Acknowledgments: We are thankful to Christian Ahrens and Ulrich Omasits for initial help with the RNA-seq analysis and to Christian Ahrens for critical feedback on the manuscript. We thank Leo Eberl for continued support and discussions. We acknowledge the Functional Genomics Center Zurich (FGCZ) for generating the RNA-seq data. Many thanks to Prof. Hans-Martin Fischer and his lab for advice and for letting us use the gas chromatography and gas station at the Institute of Microbiology at the ETH Zürich. We are grateful to the editor and the three reviewers for their useful comments. This work was supported by the Swiss National Science Foundation (31003A_153374 to Gabriella Pessi).

Author Contributions: M.L. and G.P. conceived and designed the experiments; M.L. and Y.L. performed the experiments; M.L. and G.P. analyzed the data; S.B.d.C. and G.Pu. contributed to the construction of the mutant strains; M.L. and G.P. wrote the paper.

Conflicts of Interest: The authors declare no conflict of interest. The founding sponsors had no role in the design of the study, in the collection, analyses, or interpretation of data, in the writing of the manuscript, and in the decision to publish the results. 


\section{References}

1. Vitousek, P.M.; Hättenschwiler, S.; Olander, L.; Allison, S. Nitrogen and nature. Ambio 2002, 31, 97-101. [CrossRef] [PubMed]

2. Moulin, L.; Munive, A.; Dreyfus, B.; Boivin-Masson, C. Nodulation of legumes by members of the $\beta$-subclass of Proteobacteria. Nature 2001, 411, 948-950. [CrossRef] [PubMed]

3. Elliott, G.N.; Chen, W.M.; Bontemps, C.; Chou, J.H.; Young, J.P.; Sprent, J.I.; James, E.K. Nodulation of Cyclopia spp. (Leguminosae, Papilionoideae) by Burkholderia tuberum. Ann. Bot. 2007, 100, 1403-1411. [CrossRef] [PubMed]

4. Elliott, G.N.; Chen, W.M.; Chou, J.H.; Wang, H.C.; Sheu, S.Y.; Perin, L.; Reis, V.M.; Moulin, L.; Simon, M.F.; Bontemps, C.; et al. Burkholderia phymatum is a highly effective nitrogen-fixing symbiont of Mimosa spp. and fixes nitrogen ex planta. New Phytol. 2007, 173, 168-180. [CrossRef] [PubMed]

5. Mishra, R.P.N.; Tisseyre, P.; Melkonian, R.; Chaintreuil, C.; Miché, L.; Klonowska, A.; Gonzalez, S.; Bena, G.; Laguerre, G.; Moulin, L. Genetic diversity of Mimosa pudica rhizobial symbionts in soils of French Guiana: investigating the origin and diversity of Burkholderia phymatum and other beta-rhizobia. FEMS Microbiol. Ecol. 2012, 79, 487-503. [CrossRef] [PubMed]

6. Chen, W.M.; Laevens, S.; Lee, T.M.; Coenye, T.; De Vos, P.; Mergeay, M.; Vandamme, P. Ralstonia taiwanensis sp. nov., isolated from root nodules of Mimosa species and sputum of a cystic fibrosis patient. Int. J. Syst. Evol. Microbiol. 2001, 51, 1729-1735. [CrossRef] [PubMed]

7. Bontemps, C.; Elliott, G.N.; Simon, M.F.; dos Reis, F.B., Jr.; Gross, E.; Lawton, R.C.; Neto, N.E.; de Fatima Loureiro, M.; De Faria, S.M.; Sprent, J.I.; et al. Burkholderia species are ancient symbionts of legumes. Mol. Ecol. 2010, 19, 44-52. [CrossRef] [PubMed]

8. Chen, W.; James, E.K.; Prescott, A.R.; Kierans, M.; Sprent, J.I. Nodulation of Mimosa spp. by the $\beta$-proteobacterium Ralstonia taiwanensis. Mol. Plant-Microbe Interact. 2003, 16, 1051-1061. [CrossRef] [PubMed]

9. Gyaneshwar, P.; Hirsch, A.M.; Moulin, L.; Chen, W.M.; Elliott, G.N.; Bontemps, C.; Estrada-de los Santos, P.; Gross, E.; dos Reis, F.B., Jr.; Sprent, J.I.; et al. Legume-nodulating betaproteobacteria: diversity, host range, and future prospects. Mol. Plant-Microbe Interact. 2011, 24, 1276-1288. [CrossRef] [PubMed]

10. Angus, A.A.; Lee, A.; Lum, M.R.; Shehayeb, M.; Hessabi, R.; Fujishige, N.A.; Yerrapragada, S.; Kano, S.; Song, N.; Yang, P.; et al. Nodulation and effective nitrogen fixation of Macroptilium atropurpureum (siratro) by Burkholderia tuberum, a nodulating and plant growth promoting beta-proteobacterium, are influenced by environmental factors. Plant Soil 2013, 369, 543-562. [CrossRef]

11. Beukes, C.W.; Venter, S.N.; Law, I.J.; Phalane, F.L.; Steenkamp, E.T. South African papilionoid legumes are nodulated by diverse Burkholderia with unique nodulation and nitrogen-fixation loci. PLOS ONE 2013, 8, e68406. [CrossRef] [PubMed]

12. Garau, G.; Yates, R.J.; Deiana, P.; Howieson, J.G. Novel strains of nodulating Burkholderia have a role in nitrogen fixation with papilionoid herbaceous legumes adapted to acid, infertile soils. Soil Biol. Biochem. 2009, 41, 125-134. [CrossRef]

13. Howieson, J.G.; De Meyer, S.E.; Vivas-Marfisi, A.; Ratnayake, S.; Ardley, J.K.; Yates, R.J. Novel Burkholderia bacteria isolated from Lebeckia ambigua-A perennial suffrutescent legume of the fynbos. Soil Biol. Biochem. 2013, 60, 55-64. [CrossRef]

14. Lemaire, B.; Chimphango, S.B.M.; Stirton, C.; Rafudeen, S.; Honnay, O.; Smets, E.; Chen, W.M.; Sprent, J.; James, E.K.; Muasya, A.M. Biogeographical patterns of legume-nodulating Burkholderia spp.: From African fynbos to continental scales. Appl. Environ. Microbiol. 2016, 82, 5099-5115. [CrossRef] [PubMed]

15. Lemaire, B.; Van Cauwenberghe, J.; Verstraete, B.; Chimphango, S.; Stirton, C.; Honnay, O.; Smets, E.; Sprent, J.; James, E.K.; Muasya, A.M. Characterization of the papilionoid-Burkholderia interaction in the Fynbos biome: the diversity and distribution of beta-rhizobia nodulating Podalyria calyptrata (Fabaceae, Podalyrieae). Syst. Appl. Microbiol. 2016, 39, 41-48. [CrossRef] [PubMed]

16. Talbi, C.; Delgado, M.J.; Girard, L.; Ramírez-Trujillo, A.; Caballero-Mellado, J.; Bedmar, E.J. Burkholderia phymatum strains capable of nodulating Phaseolus vulgaris are present in Moroccan soils. Appl. Environ. Microbiol. 2010, 76, 4587-4591. [CrossRef] [PubMed] 
17. Liu, W.Y.Y.; Ridgway, H.J.; James, T.K.; James, E.K.; Chen, W.M.; Sprent, J.I.; Young, J.P.W.; Andrews, M. Burkholderia sp. induces functional nodules on the South African invasive legume Dipogon lignosus (Phaseoleae) in New Zealand Soils. Microb. Ecol. 2014, 68, 542-555. [CrossRef] [PubMed]

18. Lemaire, B.; Dlodlo, O.; Chimphango, S.; Stirton, C.; Schrire, B.; Boatwright, J.S.; Honnay, O.; Smets, E.; Sprent, J.; James, E.K.; et al. Symbiotic diversity, specificity and distribution of rhizobia in native legumes of the Core Cape Subregion (South Africa). FEMS Microbiol. Ecol. 2015, 91. [CrossRef] [PubMed]

19. Beukes, C.W.; Palmer, M.; Manyaka, P.; Chan, W.Y.; Avontuur, J.R.; van Zyl, E.; Huntemann, M.; Clum, A.; Pillay, M.; Palaniappan, K.; et al. Genome data provides high support for generic boundaries in Burkholderia sensu lato. Front. Microbiol. 2017, 8. [CrossRef] [PubMed]

20. Sawana, A.; Adeolu, M.; Gupta, R.S. Molecular signatures and phylogenomic analysis of the genus Burkholderia: Proposal for division of this genus into the emended genus Burkholderia containing pathogenic organisms and a new genus Paraburkholderia gen. nov. harboring environmental species. Front. Genet. 2014, 5, 429. [CrossRef] [PubMed]

21. Vandamme, P.; Goris, J.; Chen, W.-M.; de Vos, P.; Willems, A. Burkholderia tuberum sp. nov. and Burkholderia phymatum sp. nov., nodulate the roots of tropical legumes. Syst. Appl. Microbiol. 2002, 25, 507-512. [CrossRef] [PubMed]

22. Chen, W.M.; James, E.K.; Coenye, T.; Chou, J.H.; Barrios, E.; de Faria, S.M.; Elliott, G.N.; Sheu, S.Y.; Sprent, J.I.; Vandamme, P. Burkholderia mimosarum sp. nov., isolated from root nodules of Mimosa spp. from Taiwan and South America. Int. J. Syst. Evol. Microbiol. 2006, 56, 1847-1851. [CrossRef] [PubMed]

23. Chen, W.M.; de Faria, S.M.; James, E.K.; Elliott, G.N.; Lin, K.Y.; Chou, J.H.; Sheu, S.Y.; Cnockaert, M.; Sprent, J.I.; Vandamme, P. Burkholderia nodosa sp. nov., isolated from root nodules on the woody Brazilian legumes Mimosa bimucronata and Mimosa scabrella. Int. J. Syst. Evol. Microbiol. 2007, 57, 1055-1059. [CrossRef] [PubMed]

24. Chen, W.M.; de Faria, S.M.; Chou, J.H.; James, E.K.; Elliott, G.N.; Sprent, J.I.; Bontemps, C.; Young, J.P.W.; Vandamme, P. Burkholderia sabiae sp. nov., isolated from root nodules of Mimosa caesalpiniifolia. Int. J. Syst. Evol. Microbiol. 2008, 58, 2174-2179. [CrossRef] [PubMed]

25. Bournaud, C.; de Faria, S.M.; Ferreira dos Santos, J.M.; Tisseyre, P.; Silva, M.; Chaintreuil, C.; Gross, E.; James, E.K.; Prin, Y.; Moulin, L. Burkholderia species are the most common and preferred nodulating symbionts of the Piptadenia Group (tribe Mimoseae). PLoS ONE 2013, 8, e63478. [CrossRef] [PubMed]

26. Sheu, S.Y.; Chou, J.H.; Bontemps, C.; Elliott, G.N.; Gross, E.; dos Reis, F.B., Jr.; Melkonian, R.; Moulin, L.; James, E.K.; Sprent, J.I.; et al. Burkholderia diazotrophica sp. nov., isolated from root nodules of Mimosa spp. Int. J. Syst. Evol. Microbiol. 2013, 63, 435-441. [CrossRef] [PubMed]

27. Martínez-Aguilar, L.; Salazar-Salazar, C.; Méndez, R.D.; Caballero-Mellado, J.; Hirsch, A.M.; Vásquez-Murrieta, M.S.; Estrada-de Los Santos, P. Burkholderia caballeronis sp. nov., a nitrogen fixing species isolated from tomato (Lycopersicon esculentum) with the ability to effectively nodulate Phaseolus vulgaris. Antonie Van Leeuwenhoek 2013, 104, 1063-1071. [CrossRef] [PubMed]

28. De Meyer, S.E.; Cnockaert, M.; Ardley, J.K.; Maker, G.; Yates, R.; Howieson, J.G.; Vandamme, P. Burkholderia sprentiae sp. nov., isolated from Lebeckia ambigua root nodules. Int. J. Syst. Evol. Microbiol. 2013, 63, 3950-3957. [CrossRef] [PubMed]

29. De Meyer, S.E.; Cnockaert, M.; Ardley, J.K.; Trengove, R.D.; Garau, G.; Howieson, J.G.; Vandamme, P. Burkholderia rhynchosiae sp. nov., isolated from Rhynchosia ferulifolia root nodules. Int. J. Syst. Evol. Microbiol. 2013, 63, 3944-3949. [CrossRef] [PubMed]

30. De Meyer, S.E.; Cnockaert, M.; Ardley, J.K.; Van Wyk, B.E.; Vandamme, P.A.; Howieson, J.G. Burkholderia dilworthii sp. nov., isolated from Lebeckia ambigua root nodules. Int. J. Syst. Evol. Microbiol. 2014, 64, 1090-1095. [CrossRef] [PubMed]

31. Mavengere, N.R.; Ellis, A.G.; Le Roux, J.J. Burkholderia aspalathi sp. nov., isolated from root nodules of the South African legume Aspalathus abietina Thunb. Int. J. Syst. Evol. Microbiol. 2014, 64, 1906-1912. [CrossRef] [PubMed]

32. Steenkamp, E.T.; van Zyl, E.; Beukes, C.W.; Avontuur, J.R.; Chan, W.Y.; Palmer, M.; Mthombeni, L.S.; Phalane, F.L.; Sereme, T.K.; Venter, S.N. Burkholderia kirstenboschensis sp. nov. nodulates papilionoid legumes indigenous to South Africa. Syst. Appl. Microbiol. 2015, 38, 545-554. [CrossRef] [PubMed] 
33. Sheu, S.Y.; Chen, M.H.; Liu, W.Y.Y.; Andrews, M.; James, E.K.; Ardley, J.K.; De Meyer, S.E.; James, T.K.; Howieson, J.G.; Coutinho, B.G.; Chen, W.M. Burkholderia dipogonis sp. nov, isolated from root nodules of Dipogon lignosus in New Zealand and Western Australia. Int. J. Syst. Evol. Microbiol. 2015, 65, 4716-4723. [CrossRef] [PubMed]

34. Bournaud, C.; Moulin, L.; Cnockaert, M.; de Faria, S.; Prin, Y.; Severac, D.; Vandamme, P. Paraburkholderia piptadeniae sp. nov. and Paraburkholderia ribeironis sp. nov., two root-nodulating symbiotic species of Piptadenia gonoacantha in Brazil. Int. J. Syst. Evol. Microbiol. 2017, 67, 432-440. [CrossRef] [PubMed]

35. Estrada-de los Santos, P.; Rojas-Rojas, F.U.; Tapia-García, E.Y.; Vásquez-Murrieta, M.S.; Hirsch, A.M. To split or not to split: An opinion on dividing the genus Burkholderia. Ann. Microbiol. 2016, 66, 1303-1314. [CrossRef]

36. Dixon, R.; Kahn, D. Genetic regulation of biological nitrogen fixation. Nat. Rev. Microbiol. 2004, 2, 621-631. [CrossRef] [PubMed]

37. Schmitz, R.A.; Klopprogge, K.; Grabbe, R. Regulation of nitrogen fixation in Klebsiella pneumoniae and Azotobacter vinelandii: NifL, transducing two environmental signals to the nif transcriptional activator NifA. J. Mol. Microbiol. Biotechnol. 2002, 4, 235-242. [PubMed]

38. Fischer, H.M. Genetic regulation of nitrogen fixation in rhizobia. Microbiol. Rev. 1994, 58, 352-386. [PubMed]

39. Bobik, C.; Meilhoc, E.; Batut, J. FixJ: A major regulator of the oxygen limitation response and late symbiotic functions of Sinorhizobium meliloti. J. Bacteriol. 2006, 188, 4890-4902. [CrossRef] [PubMed]

40. Terpolilli, J.J.; Hood, G.A.; Poole, P.S. What determines the efficiency of $\mathrm{N}_{2}$-fixing Rhizobium-legume symbioses? Adv. Microb. Physiol. 2012, 60, 325-389. [PubMed]

41. MacLean, A.M.; Finan, T.M.; Sadowsky, M.J. Genomes of the symbiotic nitrogen-fixing bacteria of legumes. Plant Physiol. 2007, 144, 615-622. [CrossRef] [PubMed]

42. Amadou, C.; Pascal, G.; Mangenot, S.; Glew, M.; Bontemps, C.; Capela, D.; Carrere, S.; Cruveiller, S.; Dossat, C.; Lajus, A.; et al. Genome sequence of the beta-rhizobium Cupriavidus taiwanensis and comparative genomics of rhizobia. Genome Res. 2008, 18, 1472-1483. [CrossRef] [PubMed]

43. Tian, C.F.; Zhou, Y.J.; Zhang, Y.M.; Li, Q.Q.; Zhang, Y.Z.; Li, D.F.; Wang, S.; Wang, J.; Gilbert, L.B.; Li, Y.R.; et al. Comparative genomics of rhizobia nodulating soybean suggests extensive recruitment of lineage-specific genes in adaptations. Proc. Natl. Acad. Sci. USA 2012, 109, 8629-8634. [CrossRef] [PubMed]

44. De Meyer, S.E.; Briscoe, L.; Martínez-Hidalgo, P.; Agapakis, C.M.; Estrada-de los Santos, P.; Seshadri, R.; Reeve, W.; Weinstock, G.; O’Hara, G.; Howieson, J.G.; et al. Symbiotic Burkholderia species show diverse arrangements of nif/fix and nod genes and lack typical high-affinity cytochrome $c b b 3$ oxidase genes. Mol. Plant-Microbe Interact. 2016, 29, 609-619. [CrossRef] [PubMed]

45. Liu, X.; Wei, S.; Wang, F.; James, E.K.; Guo, X.; Zagar, C.; Xia, L.G.; Dong, X.; Wang, Y.P. Burkholderia and Cupriavidus spp. are the preferred symbionts of Mimosa spp. in Southern China. FEMS Microbiol. Ecol. 2012, 80,417-426. [CrossRef] [PubMed]

46. Gehlot, H.S.; Tak, N.; Kaushik, M.; Mitra, S.; Chen, W.M.; Poweleit, N.; Panwar, D.; Poonar, N.; Parihar, R.; Tak, A.; et al. An invasive Mimosa in India does not adopt the symbionts of its native relatives. Ann. Bot. 2013, 112, 179-196. [CrossRef] [PubMed]

47. dos Reis, F.B., Jr.; Simon, M.F.; Gross, E.; Boddey, R.M.; Elliott, G.N.; Neto, N.E.; de Fatima Loureiro, M.; de Queiroz, L.P.; Scotti, M.R.; Chen, W.-M.; et al. Nodulation and nitrogen fixation by Mimosa spp. in the Cerrado and Caatinga biomes of Brazil. New Phytol. 2010, 186, 934-946. [CrossRef] [PubMed]

48. Moulin, L.; Klonowska, A.; Caroline, B.; Booth, K.; Vriezen, J.A.; Melkonian, R.; James, E.K.; Young, J.P.W.; Bena, G.; Hauser, L.; et al. Complete Genome sequence of Burkholderia phymatum STM815 ${ }^{\mathrm{T}}$, a broad host range and efficient nitrogen-fixing symbiont of Mimosa species. Stand. Genomic Sci. 2014, 9, 763-774. [CrossRef] [PubMed]

49. Miller, J.H. Experiments in Molecular Genetics; Cold Spring Harbor Lab Press: Cold Spring Harbor, NY, USA, 1972; pp. 352-355.

50. Clark, D.J.; Maaløe, M. DNA replication and the division cycle in Escherichia coli. J. Mol. Biol. 1967, $23,99-112$. [CrossRef]

51. Regensburger, B.; Hennecke, H. RNA polymerase from Rhizobium japonicum. Arch. Microbiol. 1983, 135, 103-109. [CrossRef] [PubMed]

52. Pessi, G.; Braunwalder, R.; Grunau, A.; Omasits, U.; Ahrens, C.H.; Eberl, L. Response of Burkholderia cenocepacia H111 to micro-oxia. PLoS ONE 2013, 8, e72939. [CrossRef] [PubMed] 
53. Talbi, C.; Argandoña, M.; Salvador, M.; Alché, J.D.; Vargas, C.; Bedmar, E.J.; Delgado, M.J. Burkholderia phymatum improves salt tolerance of symbiotic nitrogen fixation in Phaseolus vulgaris. Plant Soil 2012, 367, 673-685. [CrossRef]

54. Hahn, M.; Hennecke, H. Localized Mutagenesis in Rhizobium japonicum. Mol. Gen. Genet. 1984, 193, 46-52. [CrossRef]

55. Göttfert, M.; Hitz, S.; Hennecke, H. Identification of nodS and nodU, two inducible genes inserted between the Bradyrhizobium japonicum nod $Y A B C$ and nodIJ genes. Mol. Plant-Microbe Interact. 1990, 3, 308-316. [CrossRef] [PubMed]

56. Koch, M.; Delmotte, N.; Rehrauer, H.; Vorholt, J.A.; Pessi, G.; Hennecke, H. Rhizobial adaptation to hosts, a new facet in the legume root-nodule symbiosis. Mol. Plant-Microbe Interact. 2010, 23, 784-790. [CrossRef] [PubMed]

57. Lardi, M.; Bolzan de Campos, S.; Purtschert, G.; Eberl, L.; Pessi, G. Competition experiments for legume infection identify Burkholderia phymatum as a highly competitive $\beta$-rhizobium. Front. Microbiol. $2017,8$. [CrossRef] [PubMed]

58. Pessi, G.; Ahrens, C.H.; Rehrauer, H.; Lindemann, A.; Hauser, F.; Fischer, H.-M.; Hennecke, H. Genome-wide transcript analysis of Bradyrhizobium japonicum bacteroids in soybean root nodules. Mol. Plant-Microbe Interact. 2007, 20, 1353-1363. [CrossRef] [PubMed]

59. Lardi, M.; Aguilar, C.; Pedrioli, A.; Omasits, U.; Suppiger, A.; Cárcamo-Oyarce, G.; Schmid, N.; Ahrens, C.H.; Eberl, L.; Pessi, G. $\sigma^{54}$-dependent response to nitrogen limitation and virulence in Burkholderia cenocepacia H111. Appl. Environ. Microbiol. 2015, 81, 12. [CrossRef] [PubMed]

60. Anders, S.; Huber, W. Differential expression analysis for sequence count data. Genome Biol. 2010, 11, R106. [CrossRef] [PubMed]

61. Powell, S.; Szklarczyk, D.; Trachana, K.; Roth, A.; Kuhn, M.; Muller, J.; Arnold, R.; Rattei, T.; Letunic, I.; Doerks, T.; et al. eggNOG v3.0: Orthologous groups covering 1133 organisms at 41 different taxonomic ranges. Nucleic Acids Res. 2012, 40. [CrossRef] [PubMed]

62. Pfaffl, M.W. A new mathematical model for relative quantification in real-time RT-PCR. Nucleic Acids Res. 2001, 29, e45. [CrossRef] [PubMed]

63. Beringer, J.E. R Factor Transfer in Rhizobium leguminosarum. J. Gen. Microbiol. 1974, 84, 188-198. [CrossRef] [PubMed]

64. Liu, Y.; Lardi, M.; Pedrioli, A.; Eberl, L.; Pessi, G. NtrC-dependent control of exopolysaccharide synthesis and motility in Burkholderia cenocepacia H111. PLoS ONE 2017, 12, e0180362. [CrossRef] [PubMed]

65. Lardi, M.; Pessi, G. Nitrogen Sources Utilization of P. phymatum Using Biolog PM3 Plates; University of Zurich: Zurich, Switzerland, 2017.

66. Reitzer, L. Nitrogen assimilation and global regulation in Escherichia coli. Annu. Rev. Microbiol. 2003, 57, 155-176. [CrossRef] [PubMed]

67. Huergo, L.F.; Chandra, G.; Merrick, M. $\mathrm{P}_{\mathrm{II}}$ signal transduction proteins: Nitrogen regulation and beyond. FEMS Microbiol. Rev. 2013, 37, 251-283. [CrossRef] [PubMed]

68. Lardi, M.; Pessi, G. Differential Transcript Expression by P. phymarum Grown under Micro-oxic and Aerobic Conditions; University of Zurich: Zurich, Switzerland, 2017.

69. Yoshida, K.; Takemoto, Y.; Sotsuka, T.; Tanaka, K.; Takenaka, S. PhaP phasins play a principal role in poly- $\beta$-hydroxybutyrate accumulation in free-living Bradyrhizobium japonicum. BMC Microbiol. 2013, 13, 290. [CrossRef] [PubMed]

70. Labes, M.; Rastogi, V.; Watson, R.; Finan, T.M. Symbiotic nitrogen fixation by a nifA deletion mutant of Rhizobium meliloti: The role of an unusual $n t r C$ allele. J. Bacteriol. 1993, 175, 2662-2673. [CrossRef] [PubMed]

71. Zhao, K.; Liu, M.; Burgess, R.R. Promoter and regulon analysis of nitrogen assimilation factor, $\sigma^{54}$, reveal alternative strategy for E. coli MG1655 flagellar biosynthesis. Nucleic Acids Res. 2009, 38, 1273-1283. [CrossRef] [PubMed]

72. van Heeswijk, W.C.; Westerhoff, H.V.; Boogerd, F.C. Nitrogen assimilation in Escherichia coli: Putting molecular data into a systems perspective. Microbiol. Mol. Biol. Rev. 2013, 77, 628-695. [CrossRef] [PubMed]

73. Lee, H.I.; Donati, A.J.; Hahn, D.; Tisa, L.S.; Chang, W.S. Alteration of the exopolysaccharide production and the transcriptional profile of free-living Frankia strain CcI3 under nitrogen-fixing conditions. Appl. Microbiol. Biotechnol. 2013, 97, 10499-10509. [CrossRef] [PubMed] 
74. Williams, A.; Wilkinson, A.; Krehenbrink, M.; Russo, D.M.; Zorreguieta, A.; Downie, J.A. Glucomannan-mediated attachment of Rhizobium leguminosarum to pea root hairs is required for competitive nodule infection. J. Bacteriol. 2008, 190, 4706-4715. [CrossRef] [PubMed]

75. Downie, J.A. The roles of extracellular proteins, polysaccharides and signals in the interactions of rhizobia with legume roots. FEMS Microbiol. Rev. 2010, 34, 150-170. [CrossRef] [PubMed]

76. Scharf, B.E.; Hynes, M.F.; Alexandre, G.M. Chemotaxis signaling systems in model beneficial plant-bacteria associations. Plant Mol. Biol. 2016, 90, 549-559. [CrossRef] [PubMed]

77. Liang, Y.Y.; Arsène, F.; Elmerich, C. Characterization of the ntrBC genes of Azospirillam brasilense Sp7: Their involvement in the regulation of nitrogenase synthesis and activity. Mol. Gen. Genet. 1993, 240, 188-196. [CrossRef] [PubMed]

78. Hakoyama, T.; Niimi, K.; Watanabe, H.; Tabata, R.; Matsubara, J.; Sato, S.; Nakamura, Y.; Tabata, S.; Jichun, L.; Matsumoto, T.; et al. Host plant genome overcomes the lack of a bacterial gene for symbiotic nitrogen fixation. Nature 2009, 462, 514-517. [CrossRef] [PubMed]

79. McLean, P.A.; Dixon, R.A. Requirement of nifV gene for production of wild-type nitrogenase enzyme in Klebsiella pneumoniae. Nature 1981, 292, 655-656. [CrossRef] [PubMed]

80. Mora, Y.; Diaz, R.; Vargas-Lagunas, C.; Peralta, H.; Guerrero, G.; Aguilar, A.; Encarnacion, S.; Girard, L.; Mora, J. Nitrogen-fixing rhizobial strains isolated from common bean seeds: Phylogeny, physiology, and genome analysis. Appl. Environ. Microbiol. 2014, 80, 5644-5654. [CrossRef] [PubMed]

81. Yamaura, M.; Uchiumi, T.; Higashi, S.; Abe, M.; Kucho, K.I. Identification by suppression subtractive hybridization of Frankia genes induced under nitrogen-fixing conditions. Appl. Environ. Microbiol. 2010, 76, 1692-1694. [CrossRef] [PubMed]

82. Chen, W.M.; Prell, J.; James, E.K.; Sheu, D.S.; Sheu, S.Y. Biosynthesis of branched-chain amino acids is essential for effective symbioses between betarhizobia and Mimosa pudica. Microbiology 2012, 158, 1758-1766. [CrossRef] [PubMed]

83. Chen, W.M.; Prell, J.; James, E.K.; Sheu, D.S.; Sheu, S.Y. Effect of phosphoglycerate mutase and fructose 1,6-bisphosphatase deficiency on symbiotic Burkholderia phymatum. Microbiology 2012, 158, 1127-1136. [CrossRef] [PubMed]

84. Green, L.S.; Karr, D.B.; Emerich, D.W. Isocitrate dehydrogenase and glyoxylate cycle enzyme activities in Bradyrhizobium japonicum under various growth conditions. Arch. Microbiol. 1998, 169, 445-451. [CrossRef] [PubMed]

85. Delmotte, N.; Ahrens, C.H.; Knief, C.; Qeli, E.; Koch, M.; Fischer, H.M.; Vorholt, J.A.; Hennecke, H.; Pessi, G. An integrated proteomics and transcriptomics reference data set provides new insights into the Bradyrhizobium japonicum bacteroid metabolism in soybean root nodules. Proteomics 2010, 10, 1391-1400. [CrossRef] [PubMed]

86. Gourion, B.; Delmotte, N.; Bonaldi, K.; Nouwen, N.; Vorholt, J.A.; Giraud, E. Bacterial RuBisCO is required for efficient Bradyrhizobium/Aeschynomene symbiosis. PLoS ONE 2011, 6, e21900. [CrossRef] [PubMed]

87. Lardi, M.; Pessi, G. Nitrogenase Activity of Bean Nodules Induced by P. phymatum nifA Mutant Strain Measured 28 Days Post Infection; University of Zurich: Zurich, Switzerland, 2017.

88. Hauser, F.; Pessi, G.; Friberg, M.; Weber, C.; Rusca, N.; Lindemann, A.; Fischer, H.M.; Hennecke, H. Dissection of the Bradyrhizobium japonicum NifA $+\sigma^{54}$ regulon, and identification of a ferredoxin gene $(f d x N)$ for symbiotic nitrogen fixation. Mol. Genet. Genomics 2007, 278, 255-271. [CrossRef] [PubMed]

89. Lardi, M.; Murset, V.; Fischer, H.M.; Mesa, S.; Ahrens, C.H.; Zamboni, N.; Pessi, G. Metabolomic profiling of Bradyrhizobium diazoefficiens-induced root nodules reveals both host plant-specific and developmental signatures. Int. J. Mol. Sci. 2016, 17, 815. [CrossRef] [PubMed]

(C) 2017 by the authors. Licensee MDPI, Basel, Switzerland. This article is an open access article distributed under the terms and conditions of the Creative Commons Attribution (CC BY) license (http:/ / creativecommons.org/licenses/by/4.0/). 